\title{
Copper Uptake in Mammary Epithelial Cells Activates Cyclins and Triggers Antioxidant Response
}

\author{
Nathália Villa dos Santos, ${ }^{1}$ Andreza Cândido Matias, ${ }^{1}$ Guilherme Shigueto Vilar Higa, \\ Alexandre Hiroaki Kihara, ${ }^{2}$ and Giselle Cerchiaro ${ }^{1}$ \\ ${ }^{1}$ Center for Natural Sciences and Humanities, Federal University of ABC (UFABC), 09210-170 Santo André, SP, Brazil \\ ${ }^{2}$ Center for Mathematics, Computation and Cognition, Federal University of ABC (UFABC), 09210-170 Santo André, SP, Brazil \\ Correspondence should be addressed to Giselle Cerchiaro; giselle.cerchiaro@ufabc.edu.br
}

Received 10 March 2015; Accepted 14 June 2015

Academic Editor: Joseph A. Adeyemi

Copyright (C) 2015 Nathália Villa dos Santos et al. This is an open access article distributed under the Creative Commons Attribution License, which permits unrestricted use, distribution, and reproduction in any medium, provided the original work is properly cited.

\begin{abstract}
The toxicologic effects of copper $(\mathrm{Cu})$ on tumor cells have been studied during the past decades, and it is suggested that $\mathrm{Cu}$ ion may trigger antiproliferative effects in vitro. However, in normal cells the toxicologic effects of high exposures of free Cu are not well understood. In this work, $\mathrm{Cu}$ uptake, the expression of genes associated with cell cycle regulation, and the levels of ROS production and related oxidative processes were evaluated in $\mathrm{Cu}$-treated mammary epithelial MCF10A nontumoral cells. We have shown that the $\mathrm{Cu}$ additive is associated with the activation of cyclin $\mathrm{D} 1$ and cyclin $\mathrm{B} 1$, as well as cyclin-dependent kinase 2 (CDK2). These nontumor cells respond to $\mathrm{Cu}$-induced changes in the oxidative balance by increase of the levels of reduced intracellular glutathione (GSH), decrease of reactive oxygen species (ROS) generation, and accumulation during progression of the cell cycle, thus preventing the cell abnormal proliferation or death. Taken together, our findings revealed an effect that contributes to prevent a possible damage of normal cells exposed to chemotherapeutic effects of drugs containing the $\mathrm{Cu}$ ion.
\end{abstract}

\section{Introduction}

Recent advances in biochemical tools have highlighted the extraordinary array of functions of $\mathrm{Cu}$ in living organisms [1]. $\mathrm{Cu}$ is required for binding to the dual specificity mitogen-activated protein kinase kinase $1 M E K 1$ and promotion of mitogen-activated protein kinase MAPK signaling and tumorigenesis by v-raf murine sarcoma viral oncogene homolog B BRAF in mammary tumors [2]. However, despite the enormous expansion in our knowledge of $\mathrm{Cu}$ biology that has occurred over the last decades, we are only just beginning to unravel the complexity of the role of this transition metal in the regulation of cellular processes and cell cycle.

$\mathrm{Cu}$ is an essential trace element and its intracellular concentrations are tightly controlled. Within the cell, $\mathrm{Cu}$ is distributed by metallochaperones and plays a fundamental role in regulating cell growth, altering gene expression (due to oxidation of guanosine and adenosine residues in nucleic acids or changes in transcription factor/growth factor activities) [3]. A critical factor in the development of cancer is angiogenesis, which endows continuous supplying of nutrients, growth factors, and signaling agents to malignant tissue [4-7]. This angiogenic response in tumor is stimulated by ceruloplasmin, the plasma $\mathrm{Cu}$-carrier $[6,8,9]$. Although these studies with cancer cells and tumors strongly suggested that $\mathrm{Cu}$ plays an essential role in cell growth and proliferation, little is known about underlying molecular mechanisms. Also, $\mathrm{Cu}$ is involved in redox reactions that generate intracellular reactive oxygen species (ROS), mainly by Fenton reaction, and a number of reports point to a relationship between $\mathrm{Cu}$, ROS production, and cancer development [10, 11], and recently the role of $\mathrm{Cu}$ metabolism in resistance of cancer cells to cisplatin [12-14]. The redox status of cells is influenced by the homeostasis of reactive species, since ROS might act as secondary messengers in the regulation of pathways associated with cell proliferation, differentiation, and apoptosis $[15,16]$. Based on these findings, some studies suggested that elevated $\mathrm{Cu}$ levels and increased oxidative stress may be used in selective cancer therapy [17, 18]; however, the effect of $\mathrm{Cu}$-stimulation in cell proliferation 
and its relationship with ROS needs to be well elucidated, especially in nontumoral cells.

The aim of the present study was to clarify the connection of the $\mathrm{Cu}$ with cell cycle activation in normal epithelial cells and to determine the mechanism by which this ion, supplied as $\mathrm{CuSO}_{4}$, stimulates the cell cycle of breast epithelial cells in vitro. For this purpose, the $\mathrm{Cu}$ uptake, the expression of genes associated with cell cycle regulation, and the levels of ROS production and related oxidative processes were evaluated in $\mathrm{Cu}$-treated mammary epithelial MCF10A nontumoral cells.

\section{Methods}

2.1. Chemicals. Unless otherwise stated, chemicals were obtained from Sigma-Aldrich (USA) and were of analytical grade: solutions were prepared using Milli-Q water (Millipore, Billerica, USA).

2.2. Cell Cultures. Cell media were prepared with DNAseand RNAse-free water and filtered through $0.22 \mu \mathrm{m}$ filter membranes (Millex GV, SLGV033RS, Millipore, Billerica, USA) prior to use. Cell cultures were manipulated using sterile, disposable nonpyrogenic plastic ware and were maintained at $37^{\circ} \mathrm{C}$ in an atmosphere of $5 \% \mathrm{CO}_{2}$ in air at a relative humidity of $80 \%$. Human breast epithelial cells MCF-10A (ATCC) were cultured in a $1: 1(\mathrm{v} / \mathrm{v})$ mixture of Dulbecco's Modified Eagle's Medium (DMEM, 12100046, Gibco, Waltham, USA) and Ham's F12 nutrient mixture (HamF12, 21700-075, Gibco, Waltham, USA) supplemented with 5\% inactivated horse serum (16050-130, Gibco, Waltham, USA) $10 \mu \mathrm{g} / \mathrm{mL}$ insulin (PHC9624, Gibco, Waltham, USA), $0.020 \mu \mathrm{g} / \mathrm{mL}$ human epidermal growth factor (EGF, PHG0311, Gibco, Waltham, USA), $0.5 \mu \mathrm{g} / \mathrm{mL}$ hydrocortisone (H0888, Sigma Aldrich, St. Louis, USA), $0.10 \mu \mathrm{g} / \mathrm{mL}$ choleric toxin (C8052, Sigma Aldrich, St. Louis, USA), $100 \mathrm{U} / \mathrm{mL}$ penicillin, and $100 \mu \mathrm{g} / \mathrm{mL}$ streptomycin (P4333, Sigma Aldrich, St. Louis, USA). Cells were routinely trypsinized and inoculated onto plates at a density of $4 \times 10^{4}$ cells $/ \mathrm{cm}^{2}$. Every month, cells were cultivated in the absence of antibiotics for control purposes and subjected to routine assay using a MycoAlert Mycoplasma Detection kit (LT07, Lonza, Walkersville, USA).

2.3. Cell Proliferation Assays. MCF-10A cells were incubated in 24 -well plates at a density of $4 \times 10^{4} \mathrm{cell} / \mathrm{cm}^{2}$ for the period of $24 \mathrm{~h}$ under the conditions described above. Aliquots of freshly prepared solutions of $\mathrm{CuSO}_{4}$ were added separately to the culture medium (less than $1 \%$ of total volume) in order to attain final concentrations in the range $25.0-1000 \mu \mathrm{M}$, and the plates were incubated for further $24-48 \mathrm{~h}$. On the basis of the results obtained subsequent experiments were conducted by incubating treated cells to $\mathrm{CuSO}_{4}$ at final concentrations of $50 \mu \mathrm{M}(n=5)$ and control cells on unsupplemented medium. Typically, cells were plated onto the medium at a density of $4 \times 10^{4}$ cells $/ \mathrm{cm}^{2}$ to give monolayers of approximately $50-60 \%$ cell confluence and incubated for $48 \mathrm{~h}$. Following incubation, cells were trypsinized, washed with phosphate buffered saline (PBS: $137 \mathrm{mM} \mathrm{NaCl}$ and $2.7 \mathrm{mM} \mathrm{KCl}$ in $10 \mathrm{mM}$ phosphate buffer at pH 7.4), stained with Trypan Blue (T8154, Sigma Aldrich, St. Louis, USA), and counted under an optical microscope using a Neubauer's chamber [19].

2.4. Isolation of RNA, Synthesis of $c D N A$, and Real-Time PCR. MCF10A cells that had been plated and incubated in the presence or absence of $\mathrm{CuSO}_{4}(50 \mu \mathrm{M}, n=6)$ were homogenized in $1 \mathrm{~mL}$ TRIzol reagent (15596-026, Invitrogen, Waltham, USA) and total RNA extracted according to the protocols of the manufacturer. After air-drying, RNA was resuspended in diethylpyrocarbonate-treated water (DEPC, 40718, Sigma Aldrich, St. Louis, USA) and the concentration determined from the absorbance at $260 \mathrm{~nm}$. Residual DNA was removed using DNase I (E2215Y, GE Healthcare Life Sciences, USA) following the protocol of the manufacturer. For each reverse transcription reaction, $4 \mu \mathrm{g}$ of total RNA was mixed with $1 \mu \mathrm{L}$ oligo(dT) [11-17] primer $(0.5 \mu \mathrm{g} / \mu \mathrm{L}$; Invitrogen, Waltham, USA) and incubated for 10 minutes at $65^{\circ} \mathrm{C}$. The mixture was then chilled on ice, mixed with $4 \mu \mathrm{L}$ of $5 \mathrm{x}$ first strand buffer, $2 \mu \mathrm{L}$ of $0.1 \mathrm{M}$ DTT (R0861, Thermo Scientific, Waltham, USA) $1 \mu \mathrm{L}$ of dATP, dTTP, dCTP, and dGTP (each $10 \mathrm{Mm}$, AM8200, Invitrogen, Waltham, USA), $1 \mu \mathrm{L}$ of SuperScript III reverse transcriptase (200 U; 18080-044, Invitrogen, Waltham, USA), and sterile water to a final volume of $20 \mu \mathrm{L}$, incubated for 60 minutes at $50^{\circ} \mathrm{C}$ and subsequently inactivated by heating at $70^{\circ} \mathrm{C}$ for 15 minutes. Real-time PCR was carried out using a Corbett Life Science Rotor-Gene 6000 thermal cycler (Qiagen) with specific primers for human cyclin D1 (forward: $5^{\prime}$-TGGGTCTGT GCATTTCTGGTT-3', reverse: $5^{\prime}$-GCTGGAA ACATGCCGGTTAC-3') and cyclin B1 (forward: 5'-AGGAACTCGAAAATTAATGCT GAAA$3^{\prime}$, reverse: $5^{\prime}$-CCGTAGGAACGCGC TTTG-3'). As an internal control, glyceraldehyde 3-phosphate dehydrogenase $(\mathrm{GAPDH})$ gene expression was determined with specific primers (forward: $5^{\prime}$-CCACCCATGGC AAATTCC$3^{\prime}$, reverse: $5^{\prime}$-TGGGATTTCCATT GATGACAAG-3'). PCR assays were performed using the following program: carryover prevention for 2 minutes at $50^{\circ} \mathrm{C}$ and initial activation for 10 minutes at $95^{\circ} \mathrm{C}$, followed by two-step cycling for 10 seconds at $95^{\circ} \mathrm{C}$ (denaturation) and 1 minute at $60^{\circ} \mathrm{C}$ (annealing/extension). Dissociation curves of PCR products were obtained by heating samples from 60 to $95^{\circ} \mathrm{C}$ in order to evaluate primer specificity.

2.5. Analysis of PCR Data. The relative levels of expression of target genes were evaluated using the comparative cycle threshold method as described by Medhurst et al. [20]. A value for $C_{T}$ was determined from the fluorescence detected within the geometric region of the semilog amplification plot and represented the PCR cycle number at which fluorescence was detectable above an arbitrary threshold established on the basis of the variability of baseline data during the first 15 cycles.

2.6. Solid Sampling in Graphite Furnace Atomic Absorption Spectroscopy (GFAAS). Experimental parameters were obtained from Carvalho Do Lago et al. [21] and the new developed methodology with dried cells [20]. Briefly, a model ZEEnit 600 (Analytik Jena) atomic absorption spectrometer, 
equipped with a transversely heated graphite atomizer, an inverse and transversal 2- and 3-field mode Zeeman effect background corrector, manual sampling accessory, and hollow $\mathrm{Cu}$ cathode lamp, was employed to determine intracellular $\mathrm{Cu}$ concentrations. Pyrolytically coated heated graphite tubes and pyrolytically coated boat-type solid sampling platforms were employed throughout. Argon (99.998\% v/v; Air Liquide, Mauá, Brasil) was used as protective and purge gas. All measurements were based on integrated absorbance values acquired with the aid of Windows NT software.

\subsection{Determination of Cu Content of Cultured Cells. MCF10A} cells that had been plated and incubated in the presence or absence of $\mathrm{CuSO}_{4}(50.0 \mu \mathrm{M})$ as described above were trypsinized and adherent cells were combined, washed five times with phosphate buffered saline (PBS: $137 \mathrm{mM} \mathrm{NaCl}$ and $2.7 \mathrm{mM} \mathrm{KCl}$ in $10 \mathrm{mM}$ phosphate buffer at $\mathrm{pH}$ 7.4) containing $1.0 \mathrm{mM}$ EDTA in order to remove residual $\mathrm{Cu}(\mathrm{II})$, and dried for 1 week in a desiccator. Experiments were conducted in triplicate or quintuplicate using plates of surface area 75 or $150 \mathrm{~cm}^{2}$. For the GFAAS determination of $\mathrm{Cu}$, procedures were followed as from Carvalho Do Lago et al. [21].

2.8. Extraction of Nuclei. Nuclei from MCF10A cells that had been incubated in the presence or absence of $\mathrm{CuSO}_{4}$ $(50.0 \mu \mathrm{M})$ as described above were isolated using published procedures $[22,23]$. Briefly, cells were inoculated at a density of $4 \times 10^{4} \mathrm{cell} / \mathrm{cm}^{2}$ into culture bottles containing appropriate medium ( $150 \mathrm{~cm}^{2}$ surface area of culture) and incubated for 48 hours at $37^{\circ} \mathrm{C}$ in an atmosphere of $5 \% \mathrm{CO}_{2}$ in air at a relative humidity of $80 \%$. Experiments were conducted in quadruplicate. Following incubation, cells were trypsinized and adherent cells were combined, washed with PBS, and centrifuged $\left(250-300 \times \mathrm{g}, 10\right.$ minutes, $\left.4^{\circ} \mathrm{C}\right)$ and the pellet was resuspended in $2 \mathrm{~mL}$ of lysis buffer $(10 \mathrm{mM} \mathrm{NaCl}, 3 \mathrm{mM}$ $\mathrm{MgCl}_{2}$, and $0.5 \%$ Tergitol NP-40 in $10 \mathrm{mM}$ Tris buffer at $\mathrm{pH}$ $7.5)$ and left on ice for 5 minutes. Cells were subsequently centrifuged $\left(500 \times \mathrm{g}, 5\right.$ minutes, $\left.4^{\circ} \mathrm{C}\right)$ and the pellet was resuspended in $2 \mathrm{~mL}$ of lysis buffer and recentrifuged. The pellet from the second centrifugation (containing extracted nuclei) was dried in an oven at $30^{\circ} \mathrm{C}$ and subsequently analyzed by GFAAS. The purities of the extracted nuclei were determined by Western blot analyses using rabbit antihistone $\mathrm{H} 3 \mathrm{~N}$ terminal and rabbit anti-human $\mathrm{Cu} / \mathrm{Zn}$ SOD1 polyclonal antibodies.

2.9. Generation of Intracellular Reactive Oxygen Species. MCF10A cells that had been plated and incubated in the presence or absence of $\mathrm{CuSO}_{4}(50.0 \mu \mathrm{M})$ were treated with trypsin/EDTA (1 mM, 25200-056, Gibco, Waltham, USA) solution, washed three times with PBS, and suspended in a $50.0 \mu \mathrm{M}$ solution of the oxidation-sensitive nonfluorescent probe $2^{\prime}, 7^{\prime}$-dichlorodihydrofluorescein diacetate (DCFH, D6883, Sigma Aldrich, St. Louis, USA) [24, 25]. Following incubation at $37^{\circ} \mathrm{C}$ for 45 minutes [19], the cells were washed three times with PBS and the levels of intracellular fluorescence were determined immediately by flow cytometry at 530 nm using a Cytomics FC 500 MPL (Beckman Coulter) instrument [26, 27]. Assays were conducted at least in quintuplicate and $>20,000$ viable cells from each sample were analyzed per assay, in arbitrary units of fluorescence.

2.10. Determination of GSH/GSSG Ratio. MCF10A cells that had been plated and incubated in the presence or absence of $\mathrm{CuSO}_{4}(50.0 \mu \mathrm{M})$ as described above were trypsinized and adherent cells were combined, washed three times with cold $\mathrm{PBS}$, and centrifuged $\left(1500 \times \mathrm{g}, 3\right.$ minutes, $\left.4^{\circ} \mathrm{C}\right)$. The cells were resuspended in $400 \mu \mathrm{L}$ of cold water and lysed by freezing in a mixture of dry ice and ethanol for 10 minutes. After thawing, proteins were precipitated with $100 \mu \mathrm{L}$ of $10 \%$ sulfosalicylic acid (390275, Sigma Aldrich, St. Louis, USA) and centrifuged $\left(4000 \times \mathrm{g}, 5\right.$ minutes, $\left.4^{\circ} \mathrm{C}\right)$. The protein concentration in the pellet was determined, and the levels of GSH and GSSG in the supernatant were assessed using the protocol of Martín et al. [28]. For GSH quantification, the assay mixture contained $100 \mu \mathrm{L}$ of supernatant, $790 \mu \mathrm{L}$ of a $0.1 \mathrm{M}$ sodium phosphate buffer containing 0.05\% EDTA at pH 7.0, $100 \mu \mathrm{L}$ of $6 \mathrm{mM} 5,5^{\prime}$-dithiobis (2-nitrobenzoic acid) (DTNB, D8130, Sigma Aldrich, St. Louis, USA) dissolved in glutathione assay buffer (GAB; $125 \mathrm{mM}$ sodium phosphate containing $6.3 \mathrm{mM}$ EDTA), and $10 \mu \mathrm{L}$ glutathione reductase (55 U/mL, G3664, Sigma Aldrich, St. Louis, USA). For GSSG quantification, the assay mixture comprised $100 \mu \mathrm{L}$ of supernatant, $190 \mu \mathrm{L}$ of $0.5 \mathrm{M}$ phosphate buffer at $\mathrm{pH} 6.8,700 \mu \mathrm{L}$ of $0.3 \mathrm{mM}$ NADPH (N5130, Sigma Aldrich, St. Louis, USA), prepared in GAB, and $10 \mu \mathrm{L}$ of glutathione reductase $(55 \mathrm{U} / \mathrm{mL})$. The reaction rate was estimated from the change in absorbance at $412 \mathrm{~nm}$ after 3 minutes at $25^{\circ} \mathrm{C}$ (for $\mathrm{GSH}$ ) or at $340 \mathrm{~nm}$ after 16 minutes at $30^{\circ} \mathrm{C}$ (for GSSG) [28-30]. The accuracy of the GSH reference standard was measured with DTNB (D8130, Sigma Aldrich, St. Louis, USA), using a molar extinction coefficient of 13,600 with an absorbance of $412 \mathrm{~nm}$ [31]. GSSG was standardized by measuring the decline of NADPH in the presence of glutathione reductase, taking into consideration that the molar extinction coefficient of NADPH to be 6270 at $340 \mathrm{~nm}$ and $1 \mathrm{~mol}$ of NADPH converts $1 \mathrm{~mol}$ of GSSG to $2 \mathrm{~mol}$ of GSH [32].

2.11. Western Blot Analyses. MCF10A cells that had been plated and incubated in the presence or absence of $\mathrm{CuSO}_{4}(50.0 \mu \mathrm{M})$ as described above were treated with trypsin/EDTA (1 mM, 25200-056, Gibco, Waltham, USA) solution, washed three times with PBS, resuspended in $150 \mu \mathrm{L}$ RIPA buffer (150 mM NaCl, $5 \mathrm{mM}$ EDTA, $1 \mathrm{mM}$ dithiothreitol, 1\% Triton X-100 (X100, Sigma Aldrich, St. Louis, USA), 0.5\% sodium deoxycholate (30970, Sigma Aldrich, St. Louis, USA), and 0.1\% SDS (L3771, Sigma Aldrich, St. Louis, USA) in $50 \mathrm{mM}$ Tris at pH 7.5) containing protease inhibitor cocktail for mammalian cells (P8340, Sigma Aldrich, St. Louis, USA), and centrifuged $(14000 \times \mathrm{g}$, $20 \mathrm{~min})$. Supernatants and pellets were transferred to Eppendorf tubes and stored at $-80^{\circ} \mathrm{C}$ until being required for analysis. Protein concentrations were determined according to the method of Lowry [33] using bovine serum albumin (A2153, Sigma Aldrich, St. Louis, USA) as standard, and extracts were submitted to SDS-PAGE and blotted onto 


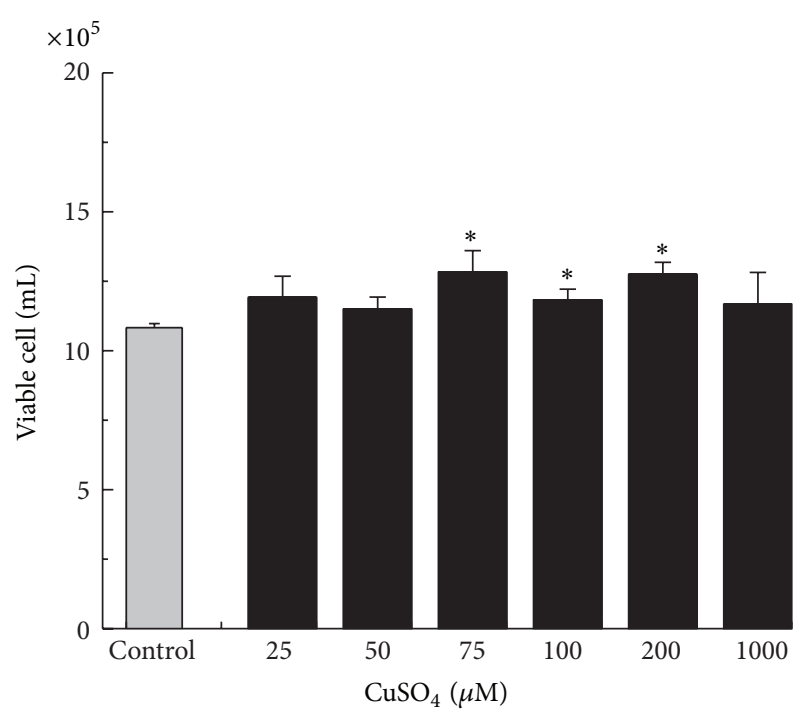

(a)

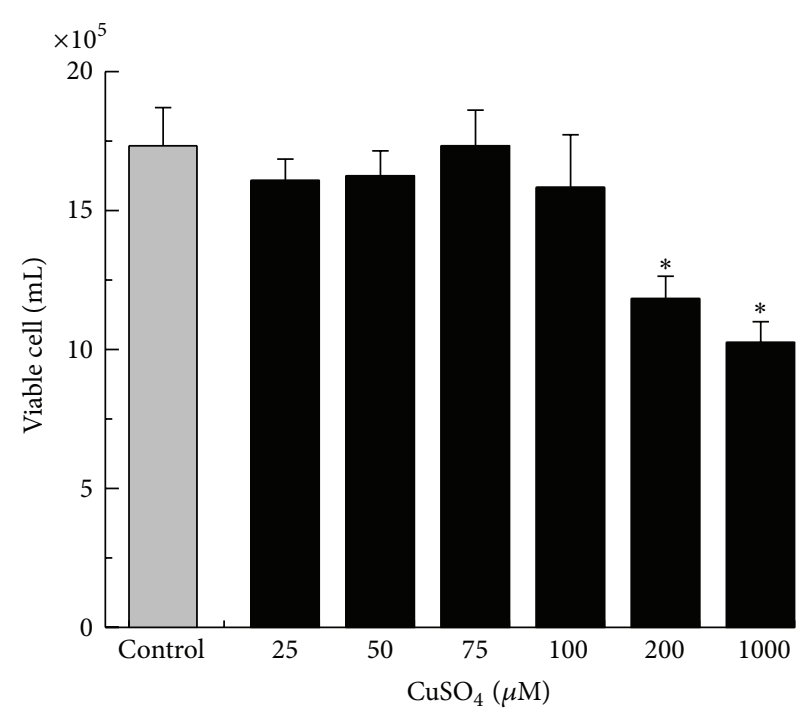

(b)

FIGURE 1: Cu treatment and the proliferation of epithelial MCF10A cells. MCF10A cells were treated with CuSO 4 for (a) 24 hours and (b) 48 hours, while untreated cells were used as control. Viable cells were counted after staining with Trypan Blue. Data represent mean values \pm standard deviation $(n=5)$. Significant differences between Cu-treated and untreated cells are indicated by asterisks $\left({ }^{*} p<0.05\right)$.

nitrocellulose membranes (10600001, GE Healthcare Life Sciences, New York, USA) with equal loading of protein being confirmed by internal mass control blotting of $\alpha$ tubulin (T9026, Sigma Aldrich, St. Louis, USA). Membranes were blocked for $1 \mathrm{hr}$ in blocking solution comprising 5\% nonfat-dried milk (M7409, Sigma Aldrich, St. Louis, USA) and $0.0025 \%$ sodium azide (V000494, Sigma Aldrich, St. Louis, USA) solubilized in TBS-T ( $150 \mathrm{mM} \mathrm{NaCl}, 50 \mathrm{mM}$ Tris at $\mathrm{pH} 7.5$, and $0.05 \%$ Tween-20) and washed twice with TBS$\mathrm{T}$. The primary antibodies employed were mouse anticyclin dependent kinase 2 (anti-CDK2 clone p34 P9OH-1 sc-51578; Santa Cruz Biotechnology, Heidelberg, Germany) and mouse anti- $\alpha$ tubulin (DM1A; Santa Cruz Biotechnology, Heidelberg, Germany) monoclonal antibodies or rabbit antihistone H3 N-terminal (H0164, Sigma Aldrich, St. Louis, USA) and rabbit anti-human $\mathrm{Cu} / \mathrm{Zn}$ superoxide dismutase 1 (AB5480, Millipore, Billerica, USA) polyclonal antibodies. The specific protein complexes formed following treatment with specific secondary antibody (anti-mouse or anti-rabbit IgG-peroxidase conjugate, A4416 or A0545, Sigma Aldrich, St. Louis, USA) were detected using SuperSignal West Pico chemiluminescent substrate (34080, Thermo Scientific, Waltham, USA).

2.12. Statistical Analyses. All experiments were repeated at least five times (except where stated otherwise) and the results are expressed as mean values \pm standard deviations. Analysis of variance (ANOVA) with the Bonferroni correction was used to evaluate the differences between means with the level of significance set at $p<0.05$. For real-time PCR experiments, values obtained for each cell lineage were entered into a two-way ANOVA with factors time and treatment, and pairwise comparisons were performed using the Tukey HSD test with the level of significance set at $p<0.05$.

\section{Results}

3.1. Viability e Test and Measurement of Intracellular Copper Levels. The effects of $\mathrm{Cu}$ on the viabilities of the nontumor line MCF10A were initially evaluated using the Trypan Blue exclusion test. On the basis of concentration-dependent studies (Figure 1), proliferation of MCF10A was not observed at concentrations above $75.0 \mu \mathrm{M} \mathrm{CuSO}_{4}$ after $24 \mathrm{hr}$ of incubation (Figure 1(a)), but cell viability was significantly reduced after $48 \mathrm{hr}$ (Figure 1(b)) when levels of $\mathrm{Cu}$ were equal to or greater than $200.0 \mu \mathrm{M}$. We did not observe differences in cell proliferation or cell death when comparing untreated and treated cells after 24 hours, $10.83 \pm 0.14 \times 10^{5}$ viable cells $/ \mathrm{mL}$ versus $11.91 \pm 0.76\left(p=7.32 \times 10^{-2}\right)$ for $25 \mu \mathrm{M} \mathrm{Cu}$, or versus $11.50 \pm 0.43\left(p=6.46 \times 10^{-2}\right)$ for $50 \mu \mathrm{M} \mathrm{Cu}$, or versus $12.83 \pm 0.76\left(p=61.12 \times 10^{-2}\right)$ for $75 \mu \mathrm{M} \mathrm{Cu}$, or versus $11.83 \pm 0.38\left(p=1.32 \times 10^{-2}\right)$ for $100 \mu \mathrm{M} \mathrm{Cu}$, or versus $12.75 \pm 0.43\left(p=1.19 \times 10^{-3}\right)$ for $200 \mu \mathrm{M} \mathrm{Cu}$, or versus $11.67 \pm 1.15\left(p=2.82 \times 10^{-1}\right)$ for $1000 \mu \mathrm{M} \mathrm{Cu}$ (Figure 1(a)). Similarly for 48 hours of $\mathrm{Cu}$ incubation we did not observe differences in cell proliferation or cell death when comparing untreated and treated cells, $17.33 \pm 1.37 \times 10^{5}$ viable cells $/ \mathrm{mL}$ versus $16.08 \pm 0.76\left(p=2.41 \times 10^{-1}\right)$ for $25 \mu \mathrm{M} \mathrm{Cu}$, or versus $16.25 \pm 0.91\left(p=3.17 \times 10^{-1}\right)$ for $50 \mu \mathrm{M} \mathrm{Cu}$, or versus $17.33 \pm 1.28(p=1)$ for $75 \mu \mathrm{M} \mathrm{Cu}$, or versus $15.83 \pm 1.89$ $\left(p=3.29 \times 10^{-1}\right)$ for $100 \mu \mathrm{M} \mathrm{Cu}$, or versus $11.83 \pm 0.80$ $\left(p=3.94 \times 10^{-3}\right)$ for $200 \mu \mathrm{M} \mathrm{Cu}$, or versus $10.25 \pm 0.75$ $\left(p=1.44 \times 10^{-3}\right)$ for $1000 \mu \mathrm{M} \mathrm{Cu}$ (Figure 1(b)). Due to the nonproliferative effect on MCF10A, the concentration of $50.0 \mu \mathrm{M} \mathrm{CuSO}_{4}$ was chosen in whole study.

The $\mathrm{Cu}$ uptake from medium supplemented with $\mathrm{CuSO}_{4}$ was evaluated by subjecting whole dried MCF10A cells to GFAA [34]. Interestingly, MCF10A cells were able 


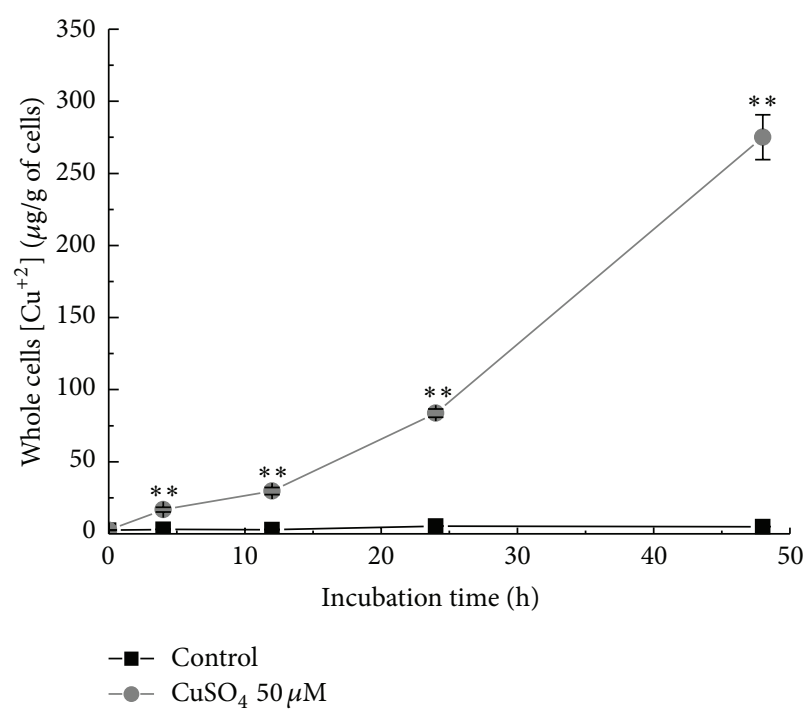

(a)
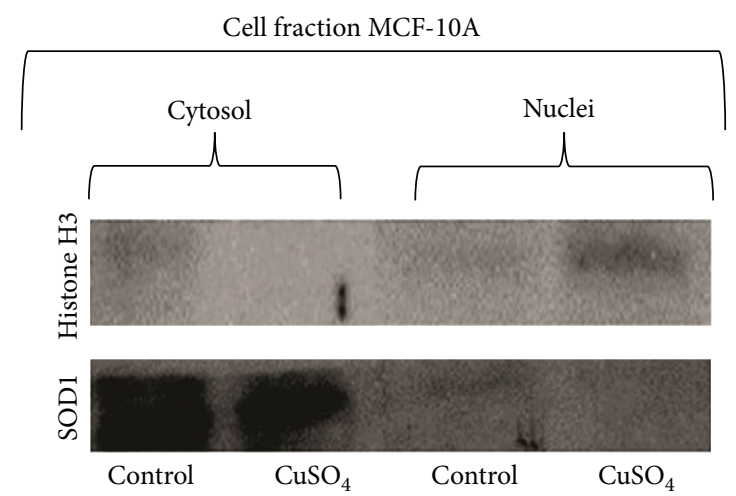

(b)

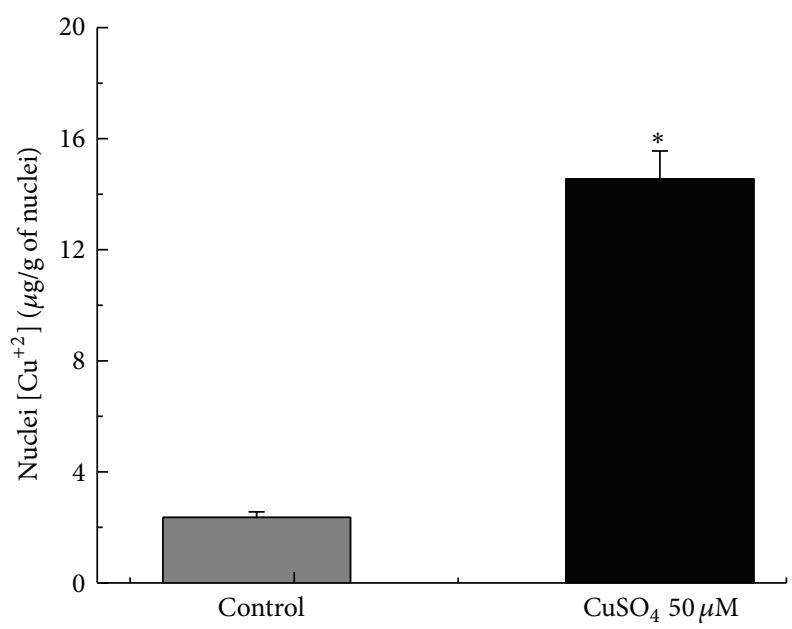

(c)

Figure 2: The uptake of $\mathrm{Cu}$ during the time, as determined by solid sampling-graphite furnace atomic absorption spectroscopy. (a) Concentration of $\mathrm{Cu}$ in whole cells of MCF10A treated with $50 \mu \mathrm{M} \mathrm{CuSO}_{4}$ and in untreated cells, during a period of 48 hours. When compared to controls, cells incubated with $50 \mu \mathrm{M}$ of $\mathrm{CuSO}_{4}$ showed higher $\mathrm{Cu}$ (II) levels after 4, 24, and 48 hours. (b) The purities of the nuclei extracted from nontumor MCF10A cells were verified by Western blot analyses. Rabbit antihistone $\mathrm{H} 3 \mathrm{~N}$-terminal and rabbit antihuman $\mathrm{Cu} / \mathrm{Zn}$-superoxide dismutase 1 polyclonal antibodies were used to detect the corresponding proteins in the cytosolic and nuclear fractions. (c) Concentration of $\mathrm{Cu}$ in the nuclei of controls and cells treated with $50 \mu \mathrm{M} \mathrm{CuSO}_{4}$ after 48 hours. Significant differences between $\mathrm{Cu}$-treated and untreated cells are indicated by asterisks $\left({ }^{*} p<0.01,{ }^{* *} p<0.001\right)$.

to internalize $\mathrm{Cu}(\mathrm{II})$. When compared to controls, cells incubated with $50 \mu \mathrm{M}$ of $\mathrm{CuSO}_{4}$ showed higher $\mathrm{Cu}(\mathrm{II})$ levels after 4 hours, $3.07 \pm 0.10 \mu \mathrm{g} / \mathrm{g}$ versus $16.76 \pm 1.63 \mu \mathrm{g} / \mathrm{g}$ $\left(p=1.51 \times 10^{3}\right)$, respectively (Figure $\left.2(\mathrm{a})\right)$. After 12 hours, differences between untreated and treated cells increased, considering the respective values $2.91 \pm 0.14 \mu \mathrm{g} / \mathrm{g}$ versus $29.61 \pm 2.46 \mu \mathrm{g} / \mathrm{g}\left(p=1.99 \times 10^{-4}\right.$, Figure $\left.2(\mathrm{a})\right)$. We also observed differences in intracellular $\mathrm{Cu}$ concentration when comparing untreated and treated cells after 24 hours, $5.36 \pm 0.13 \mu \mathrm{g} / \mathrm{g}$ versus $83.73 \pm 2.89\left(p=4.61 \times 10^{-5}\right)$, and 48 hours $4.76 \pm 0.09 \mu \mathrm{g} / \mathrm{g}$ versus $275.12 \pm 15.62(p=$ $5.03 \times 10^{-4}$ ), respectively (Figure 2(a)). Afterwards, nuclei were isolated from both treated and untreated cells and the purification was verified by measurement of the relative amounts of the exclusively nuclear protein histone $\mathrm{H} 3$ and the mainly cytosolic protein SOD by Western blot (Figure 2(b)). After all these procedures, GFAAS revealed that in fact $\mathrm{Cu}$ entered MCF10A nuclei, based on values of $\mathrm{Cu}$ concentration determined in the nuclei from controls and treated cells, $2.36 \pm 0.20 \mu \mathrm{g} / \mathrm{g}$ versus $14.55 \pm 3.01 \mu \mathrm{g} / \mathrm{g}\left(p=6.03 \times 10^{-3}\right.$, Figure 2(c)).

3.2. Real-Time PCR Analyses of Cyclins D1 and B1 in Epithelial Cell Line MCF10A. In order to assess the mechanism by 


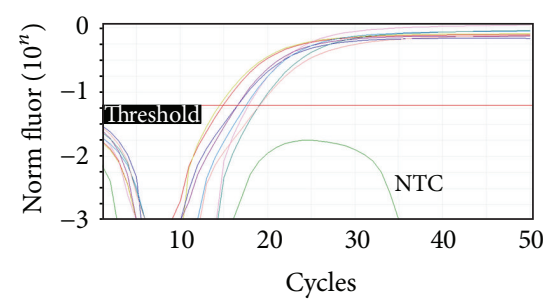

(a)

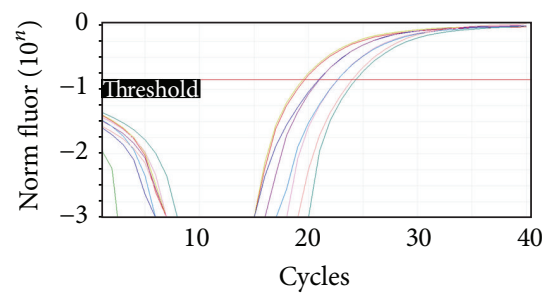

(d)

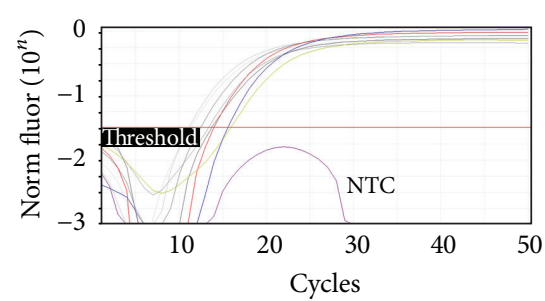

(g)

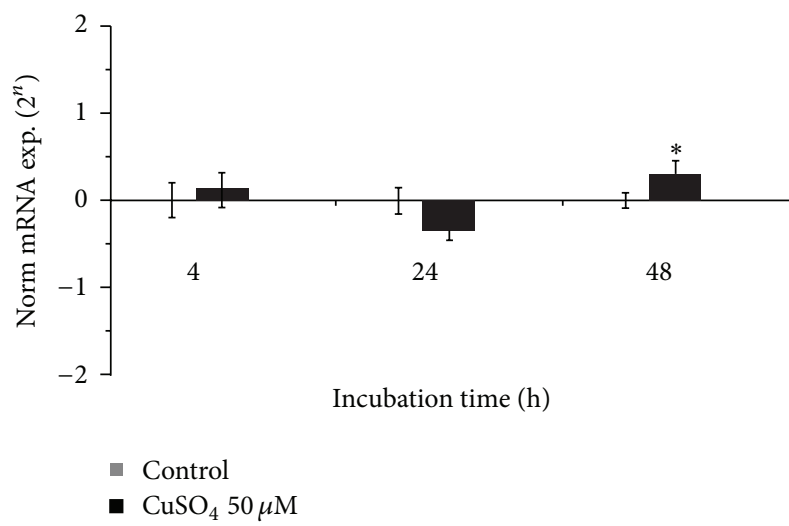

(j)

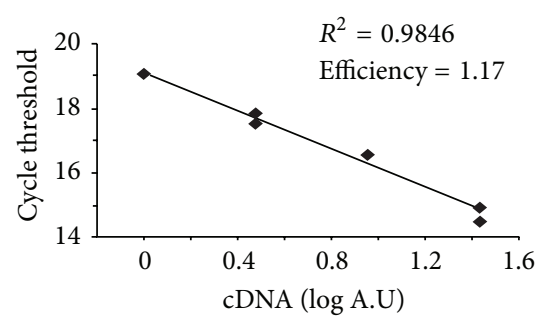

(b)

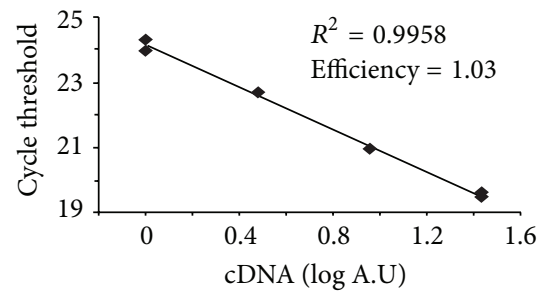

(e)

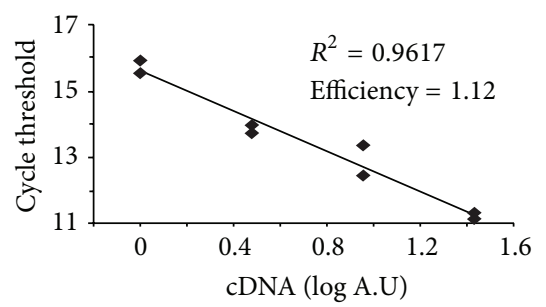

(h)

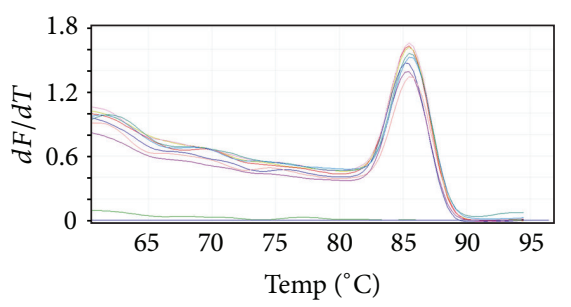

(c)

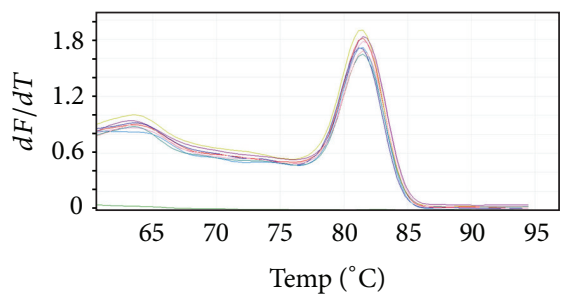

(f)

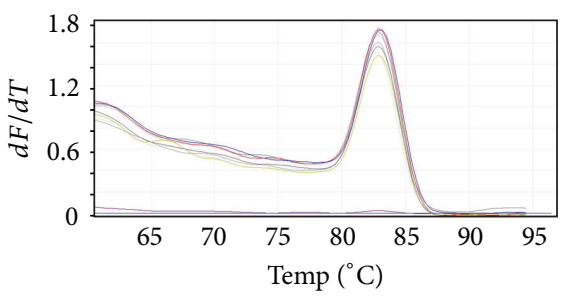

(i)

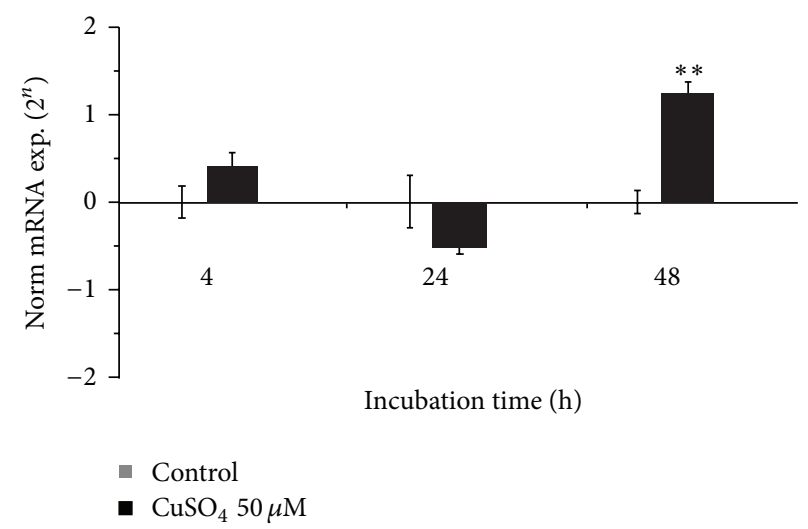

(k)

FIgURE 3: Real-time PCR revealed that Cu stimulated mild upregulation of cyclin D1 and cyclin B1 genes in MCF10A cells. Expression of cyclin genes in cells treated with $50 \mu \mathrm{M} \mathrm{CuSO}_{4}$. The results were plotted and normalized with respect to respective untreated cells. The specificities of the primers for human glyceraldehyde 3-phosphate dehydrogenase (GAPDH), cyclin D1, and cyclin B1 were verified by real time PCR. Amplification plots, linear regression, and dissociation melting curves for (a-c) cyclin D1, (d-f) cyclin B1, and (g-h) GAPDH obtained with serial dilutions of cDNA (1, 1/3,1/9, and 1/27). (j) Expression of cyclin D1 in Cu-treated MCF10A cells. Significant differences between untreated and $\mathrm{Cu}$-treated cells are indicated by asterisks $\left({ }^{*} p<0.05,{ }^{* *} p<0.001\right)$.

which $\mathrm{Cu}(\mathrm{II})$ salt stimulates cell proliferation in human epithelial cells, we investigated the regulation of genes involved in cell cycle progression. Specific primers were designed and their reliability verified on the basis of amplification plots obtained with serially diluted cDNA $(1,1 / 3,1 / 9$, and $1 / 27$ ), linear regression analyses, and dissociation melting curves. With these procedures, we validated specific primers designed for human cyclin D1 (Figures 3(a)-3(c)) and cyclin B1 (Figures 3(d)-3(f)) as well as for GAPDH (Figures 3(g)3(i)) as internal control. Real-time PCR revealed that exposure of MCF10A cells to $50 \mu \mathrm{M}$ of $\mathrm{CuSO}_{4}$ triggered upregulation of both cyclin D1 (0.297-fold induction; $23 \%$; $p=$ $1.31 \times 10^{-2}$, Figure $\left.3(j)\right)$ and cyclin B1 (1.236-fold induction; $136 \% ; p=2.96 \times 10^{-6}$, Figure $\left.3(\mathrm{k})\right)$ gene expression after 


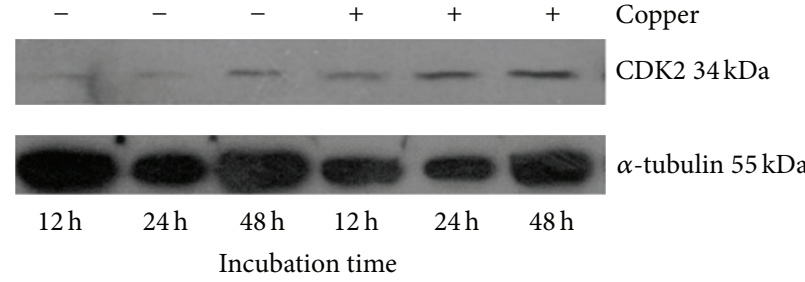

(a)

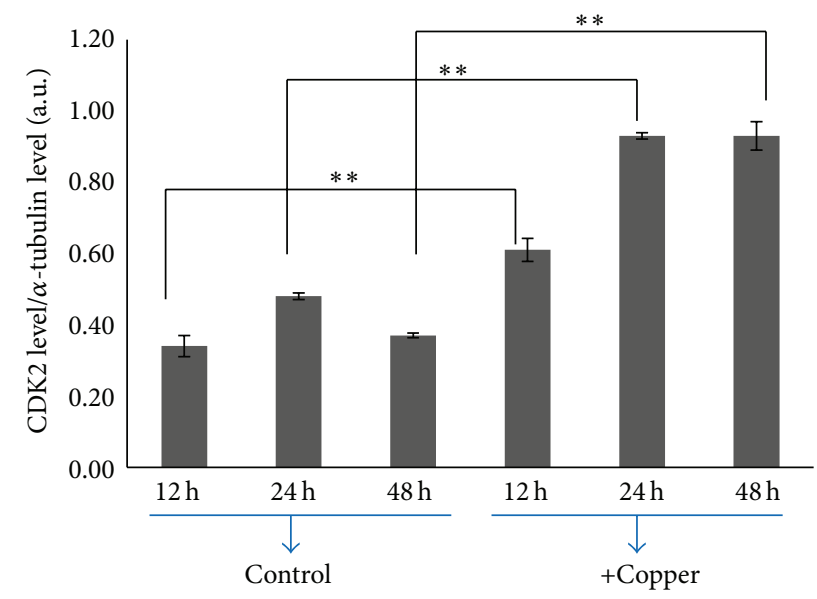

(b)

Figure 4: Western blot indicated that the expression levels of Cyclin-Dependent Kinase 2 (CDK2) was upregulated during Cu exposure in MCF10A cells. (a) CDK2 protein levels in cells treated with $50 \mu \mathrm{M} \mathrm{CuSO}_{4}$ and comparison with $\alpha$-tubulin (representative Western blots from $n=3$ ). At each time point, $100 \mu \mathrm{g}$ of proteins from the total cell lysates was loaded onto each lane for the detection of CDK2. $\alpha$-tubulin was used as loading control, and the densitometry of each lane (represented as bars) was calculated using the Image J software. (b) When compared to controls, treated cells showed augmented CDK2 levels after 12 hours. The data are expressed as arbitrary units and represent the mean $\pm \mathrm{SD}$ of $n=3$ independent experiments, ${ }^{* *} p<0.001$.

48 hours. Western blots obtained using mouse anticyclin dependent kinase 2 (anti-CDK2) and mouse anti- $\alpha$ tubulin (internal standard) as primary antibodies revealed that CDK2 expression levels were upregulated in MCF10A cells in the presence of $\mathrm{Cu}$ after $48 \mathrm{hr}$ (Figure 4 ).

3.3. Analyses of ROS Generation in Normal MCF10A Cells. The generation of intracellular ROS, in the form of hydrogen peroxide and oxygen-derived hydroxyl and carbonate free radicals, by cells that had been exposed to $\mathrm{Cu}$ (II) was estimated using the membrane-permeable nonfluorescent cell probe $\mathrm{DCFH}$, which in the oxidized form $\left(2^{\prime}, 7^{\prime}\right.$-dichlorofluorescein; DCF) is fluorescent [26, 35-37]. Figure 5(a) shows the changes in DCF fluorescence, measured at $520 \mathrm{~nm}$ by flow cytometry, during exposure of DCFH-treated MCF10 cells to $50 \mu \mathrm{M} \mathrm{CuSO}_{4}$. As early as 6 hours, fluorescence intensity in untreated MCF10A cells was significantly higher when compared to that observed in $\mathrm{Cu}$ (II)-treated cells, $69.85 \pm 5.40 \%$ versus $42.62 \pm 2.79 \%$ $\left(p=1.09 \times 10^{-4}\right)$. We also observed decrease of fluorescence intensity when comparing controls to treated cells after 12 hours, $71.57 \pm 1.86 \%$ versus $35.75 \pm 2.55 \%\left(p=4.81 \times 10^{-7}\right)$, as well as after 24 hours, $82.60 \pm 4.02 \%$ versus $42.67 \pm 1.73 \%$ $\left(p=1.74 \times 10^{-6}\right)$. Changes in the fluorescence intensity between controls and treated cells persisted after 48 hours, $86.20 \pm 1.79 \%$ versus $45.25 \pm 1.40 \%\left(p=3.05 \times 10^{-8}\right)$, respectively (Figure 5(b)).

3.4. Quantification of the Intracellular Glutathione Levels. In order to clarify the effects of $\mathrm{Cu}$ entrance in MCF10A cells, the GSH/GSSG ratios in cells that had been exposed to $\mathrm{Cu}$ (II) for 48 hours were determined as suggested by Estrela et al. [38]. We measured the total glutathione level in cell to ensure the level of this endogenous antioxidant was not changed during the $\mathrm{Cu}$ treatment. Control and $\mathrm{Cu}-$ treated cells exhibited glutathione total level of $7.35 \pm 0.76$ and $8.19 \pm 0.21(p=0.1375)$, respectively, indicating no significant changes in the total glutathione (GSH + GSSG, Figure 6(a)). Cells of MCF10A that had been incubated on control medium for 48 hours exhibited GSH/GSSG ratio of $3.20 \pm 0.05$ (Figure 6(b)). Inclusion of $\mathrm{CuSO}_{4}$ in the medium increased to $5.72 \pm 0.86(p=0.00896)$ the GSH/GSSG ratio.

\section{Discussion}

$\mathrm{Cu}$ complexes can induce apoptosis in cancer cells as a result of damage inflicted to the organelle $[19,39,40]$, and this process could engender misinterpretation of the actual effect of the free metal excess on the cell cycle of normal cells. In the present study, the culture medium was supplemented with the free salt $\mathrm{CuSO}_{4}$ in order to investigate the influence of free intracellular $\mathrm{Cu}$ on the proliferation of normal epithelial MCF10A cells in vitro. The specific choice of the free $\mathrm{Cu}$ ion and its concentration was based on results recently reported by Carvalho Do Lago et al. [21]. Also, malignant cells typically possess increased levels of oxidant species that contribute naturally to the enhancement of apoptosis [41], while the lower oxidant levels of the nonmalignant MCF10A should contribute to their resistance to $\mathrm{Cu}$-stimulated cell death.

Progression through the different phases of the cell cycle is regulated by specific combinations of cyclins and CDKs. Cyclins and CDKs can be involved in processes other than that of cell proliferation, as demonstrated by the reported association between cyclin expression and cell cycle reentry leading to apoptosis in neurodegenerative processes triggered by oxidative stress [42]. 

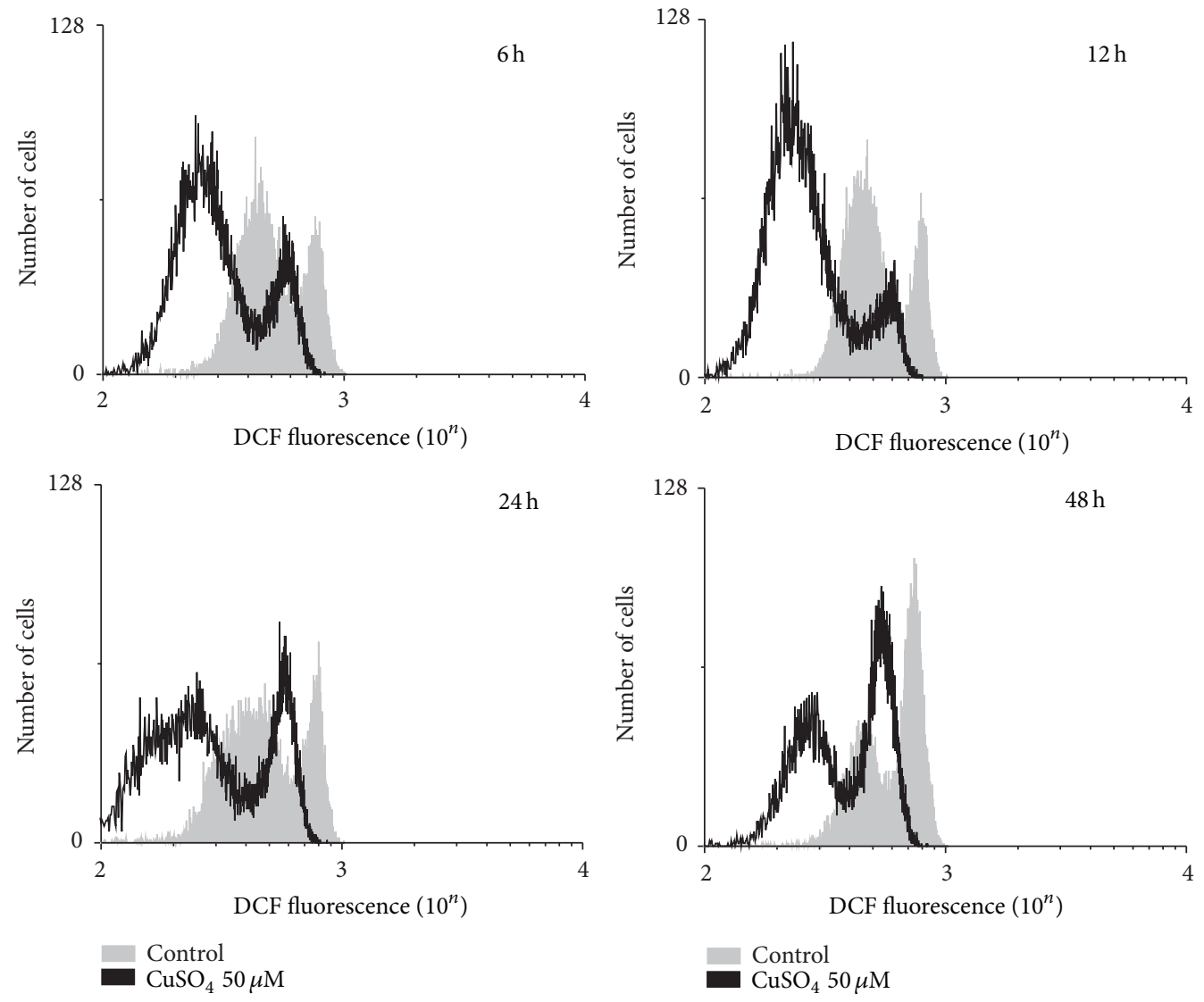

(a)

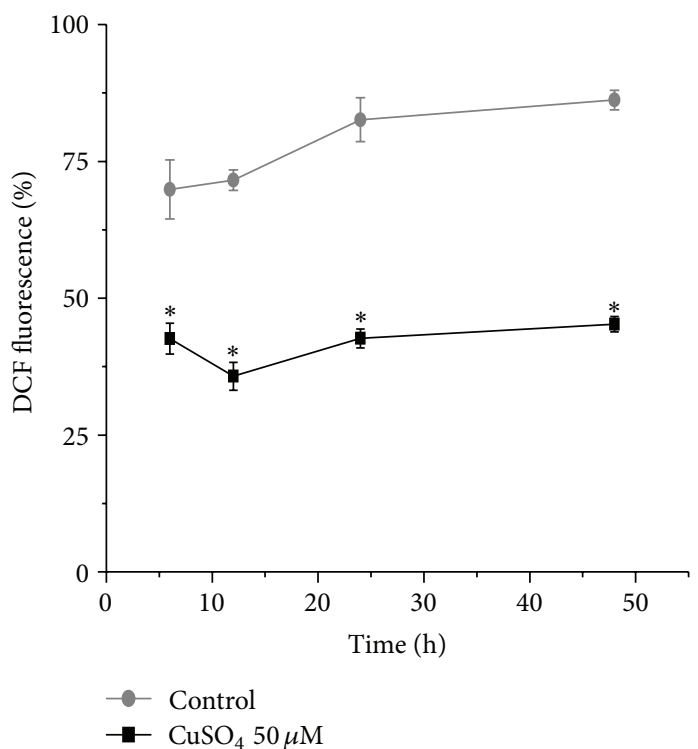

(b)

Figure 5: Cu-treated MCF10A cells produced less reactive oxygen species (ROS) than their untreated counterparts. The generation of intracellular ROS, cells that had been exposed to $\mathrm{Cu}(\mathrm{II})$, was estimated using the membrane-permeable nonfluorescent cell probe DCFH. (a) Graph representing typical distribution of number of cells according to DCF levels, in both controls and treated cells elicited by $50 \mu \mathrm{M}$ $\mathrm{CuSO}_{4}$ at specific time points, as determined by flow cytometry. (b) When compared to controls, treated cells showed reduced DCF levels after 6 hours, 12 hours, 24 hours, and 48 hours. Significant differences between untreated and Cu-treated cells are indicated by asterisk $\left({ }^{*} p<0.01\right)$. 


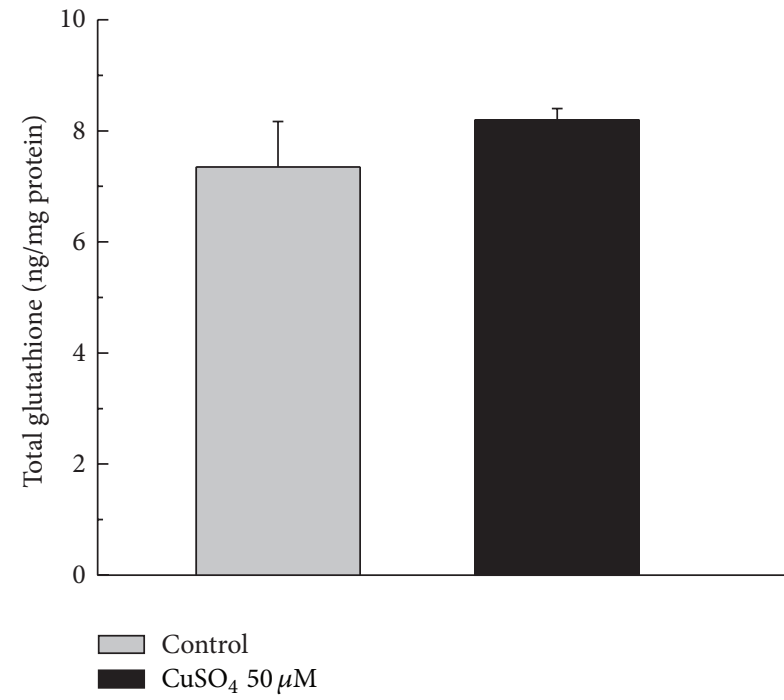

(a)

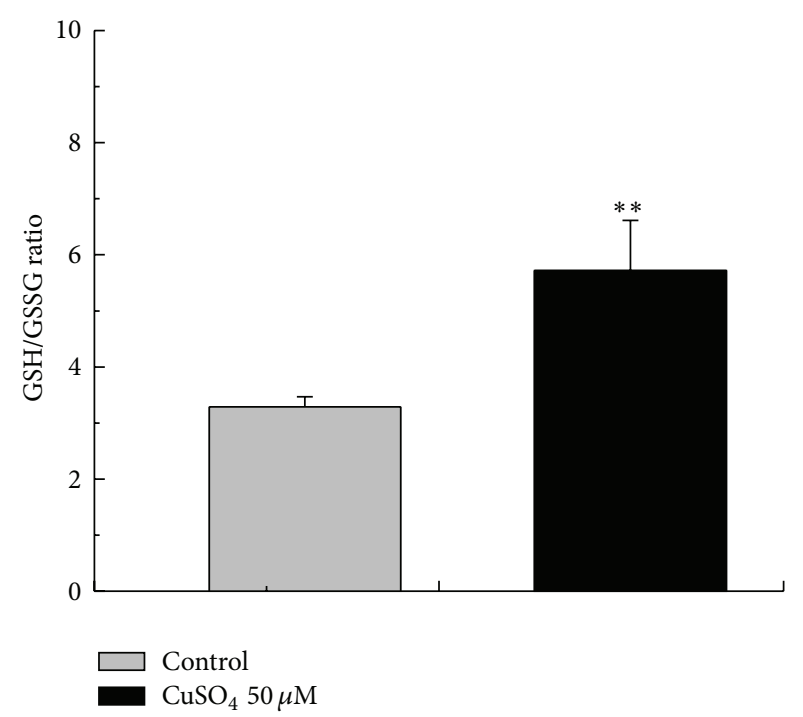

(b)

FIGURE 6: $\mathrm{Cu}$ treatment altered the redox potential of MCF10A cells. (a) Total glutathione in control and $50 \mu \mathrm{M} \mathrm{CuSO}_{4}$ treated cells after 48 hours of incubation. (b) Ratio of reduced to oxidized glutathione (GSH/GSSG) after 48 hours of incubation. Significant differences between untreated and $\mathrm{Cu}$-treated cells are indicated by asterisk $\left({ }^{*} p<0.01\right)$.

In the present study, normal MCF10A cells showed a mild upregulation of cyclins D1 and B1 on exposure to $\mathrm{Cu}$. Interestingly, we observed that cyclin B1 was upregulated when the internal concentration of $\mathrm{Cu}$ exceeded $100 \mu \mathrm{g} / \mathrm{g}$ cells, while cyclin D1 was upregulated when $\mathrm{Cu}$ concentrations were within the range $150-275 \mu \mathrm{g} / \mathrm{g}$ cells. MCF10A cells permitted the entry of $\mathrm{Cu}$ such that the internal concentration of the metal was sufficiently elevated to cause specific upregulation of cyclins mRNA levels. Indeed, $\mathrm{Cu}$ was detected in the nuclei of MCF10A cells, indicating that this ion may trigger changes in gene expression, including those related to cell cycle progression. Malignant cells typically possess increased levels of oxidant species that contribute naturally to the enhancement of proliferation [41], while the lower oxidant levels of the nonmalignant MCF10A should contribute to their resistance to $\mathrm{Cu}$-stimulated cell proliferation as we observed.

The concept that redox cycling controls the mammalian cell cycle through the modulation of intracellular antioxidant/oxidant species, particularly thiol-containing molecules such as GSH, has received much consideration in the literature (for a review [15]). In cancer cells, the GSH/GSSG ratio has been shown to influence the regulation of the cell cycle, mutagenic mechanisms, DNA synthesis, growth, and multidrug and radiation resistance, and GSH levels are typically higher in tumor tissue in comparison with normal tissue $[38,43]$. In the present study, we observed that internalization of $\mathrm{Cu}$, induced by treatment with $\mathrm{CuSO}_{4}$, decreased ROS levels and increased the GSH/GSSG ratio. $\mathrm{Cu}$ resistance has been also observed in platinum drug resistance on cancer [44]. The exposure of $\mathrm{Cu}(\mathrm{II})$ soluble in tumor mammalian cells MCF7 led to clear increase in the proliferation of the cells due to $\mathrm{Cu}$ uptake and disturbances of the redox status [45].
If we compare the degree of cell proliferation, the expression of genes associated with cell cycle regulation, and the levels of ROS production and related oxidative processes, in copper-treated mammary epithelial cell lines with equivalent metabolic rates, namely, MCF7 tumor cells [45] and the epithelial MCF10A nontumor cells, we can observe different behavior between cells. The observed copper-stimulated proliferation of tumor cells was not correlated with cyclin upregulation or increased cytosolic concentration of the metal, but rather with enhanced ROS generation and elevated levels of lipid peroxidation, which gave rise to alterations in the topography of the cell membranes [45]. In contrast, we observed here in this work that copper did not stimulate the proliferation of nontumorigenic epithelial MCF10A cells, although the enhanced intracellular uptake of the metal was accompanied by a moderate overexpression of cyclins D1 and B1, and an increase in the ratio of reduced to oxidized glutathione (GSH/GSSG).

Based on our findings, we suggest that normal mammary cells respond to increased levels of intracellular $\mathrm{Cu}$ by triggering cyclin mRNA expression and elevating the concentration of the endogenous antioxidant GSH. In turn, increased levels of antioxidant prevent abnormal ROS formation, which could cause oxidative stress and cell death. Finally, our findings point to proteins involved in cell cycle such as cyclins and $\mathrm{CDK} 2$ as a novel target for $\mathrm{Cu}$ interaction. More detailed investigation into its molecular mechanism will be important for our understanding of $\mathrm{Cu}$ metabolism in normal cells. We observed here that enhanced intracellular uptake and accumulation of $\mathrm{Cu}$ were followed by an overexpression of cyclin D1 and cyclin B1, with an increase in the ratio of reduced to oxidized glutathione (GSH/GSSG), but without ROS production. The results presented herein provide new 
insights into the molecular link between $\mathrm{Cu}$ excess and the control of cell cycle and, consequently, the mechanism by which changes in redox balance and ROS accumulation regulate cell proliferation.

\section{Conflict of Interests}

The authors declare no competing financial interests.

\section{Authors' Contribution}

Nathália Villa dos Santos and Andreza Cândido Matias contributed equally to this work.

\section{Acknowledgments}

This work was supported by São Paulo Foundation Research (FAPESP) and by National Council for Technological and Scientific Development (CNPq), Brazil.

\section{References}

[1] J. T. Rubino and K. J. Franz, "Coordination chemistry of copper proteins: how nature handles a toxic cargo for essential function," Journal of Inorganic Biochemistry, vol. 107, no. 1, pp. 129-143, 2012.

[2] D. C. Brady, M. S. Crowe, M. L. Turski et al., "Copper is required for oncogenic BRAF signalling and tumorigenesis," Nature, vol. 509, no. 7501, pp. 492-496, 2014.

[3] M. C. Linder, "Copper and genomic stability in mammals," Mutation Research/Fundamental and Molecular Mechanisms of Mutagenesis, vol. 475, no. 1-2, pp. 141-152, 2001.

[4] H. Xie and Y. J. Kang, "Role of copper in angiogenesis and its medicinal implications," Current Medicinal Chemistry, vol. 16, no. 10, pp. 1304-1314, 2009.

[5] L. Finney, S. Vogt, T. Fukai, and D. Glesne, "Copper and angiogenesis: unravelling a relationship key to cancer progression," Clinical and Experimental Pharmacology and Physiology, vol. 36, no. 1, pp. 88-94, 2009.

[6] A. Nasulewicz, A. Mazur, and A. Opolski, "Role of copper in tumour angiogenesis-clinical implications," Journal of Trace Elements in Medicine and Biology, vol. 18, no. 1, pp. 1-8, 2004.

[7] M. Rabinovitz, "Angiogenesis and its inhibition: the copper connection," Journal of the National Cancer Institute, vol. 91, no. 19, pp. 1689-1690, 1999.

[8] K. S. Raju, G. Alessandri, M. Ziche, and P. M. Gullino, "Ceruloplasmin, copper ions, and angiogenesis," Journal of the National Cancer Institute, vol. 69, no. 5, pp. 1183-1188, 1982.

[9] J. C. Juarez, O. Betancourt Jr., S. R. Pirie-Shepherd et al., "Copper binding by tetrathiomolybdate attenuates angiogenesis and tumor cell proliferation through the inhibition of superoxide dismutase 1," Clinical Cancer Research, vol. 12, no. 16, pp. 49744982, 2006.

[10] S. Y. Tsang, S. C. Tam, I. Bremner, and M. J. Burkitt, "Copper1,10-phenanthroline induces internucleosomal DNA fragmentation in HepG2 cells, resulting from direct oxidation by the hydroxyl radical," Biochemical Journal, vol. 317, no. 1, pp. 13-16, 1996.

[11] M. L. Turski and D. J. Thiele, "New roles for copper metabolism in cell proliferation, signaling, and disease," The Journal of Biological Chemistry, vol. 284, no. 2, pp. 717-721, 2009.
[12] R. Safaei, M. H. Maktabi, B. G. Blair, C. A. Larson, and S. B. Howell, "Effects of the loss of Atoxl on the cellular pharmacology of cisplatin," Journal of Inorganic Biochemistry, vol. 103, no. 3, pp. 333-341, 2009.

[13] R. Safaei, S. Otani, B. J. Larson, M. L. Rasmussen, and S. B. Howell, "Transport of cisplatin by the copper efflux transporter ATP7B," Molecular Pharmacology, vol. 73, no. 2, pp. 461-468, 2008.

[14] A. K. Boal and A. C. Rosenzweig, "Crystal structures of cisplatin bound to a human copper chaperone," Journal of the American Chemical Society, vol. 131, no. 40, pp. 14196-14197, 2009.

[15] E. H. Sarsour, M. G. Kumar, L. Chaudhuri, A. L. Kalen, and P. C. Goswami, "Redox control of the cell cycle in health and disease," Antioxidants and Redox Signaling, vol. 11, no. 12, pp. 2985-3011, 2009.

[16] H. Tsukagoshi, W. Busch, and P. N. Benfey, "Transcriptional regulation of ROS controls transition from proliferation to differentiation in the root," Cell, vol. 143, no. 4, pp. 606-616, 2010.

[17] A. Gupte and R. J. Mumper, "Elevated copper and oxidative stress in cancer cells as a target for cancer treatment," Cancer Treatment Reviews, vol. 35, no. 1, pp. 32-46, 2009.

[18] C. Duncan and A. R. White, "Copper complexes as therapeutic agents," Metallomics, vol. 4, no. 2, pp. 127-138, 2012.

[19] G. Filomeni, G. Cerchiaro, A. M. D. C. Ferreira et al., "Proapoptotic activity of novel isatin-Schiff base copper(II) complexes depends on oxidative stress induction and organelleselective damage," The Journal of Biological Chemistry, vol. 282, no. 16, pp. 12010-12021, 2007.

[20] A. D. Medhurst, D. C. Harrison, S. J. Read, C. A. Campbell, M. J. Robbins, and M. N. Pangalos, "The use of TaqMan RT-PCR assays for semiquantitative analysis of gene expression in CNS tissues and disease models," Journal of Neuroscience Methods, vol. 98, no. 1, pp. 9-20, 2000.

[21] L. C. Carvalho Do Lago, A. C. Matias, C. S. Nomura, and G. Cerchiaro, "Radical production by hydrogen peroxide/bicarbonate and copper uptake in mammalian cells: modulation by $\mathrm{Cu}$ (II) complexes," Journal of Inorganic Biochemistry, vol. 105, no. 2, pp. 189-194, 2011.

[22] M. B. Martin, S. V. Angeloni, P. Garcia-Morales et al., "Regulation of estrogen receptor- $\alpha$ expression in MCF-7 cells by taxol," Journal of Endocrinology, vol. 180, no. 3, pp. 487-496, 2004.

[23] M. Saceda, M. E. Lippman, P. Chambon et al., "Regulation of the estrogen receptor in MCF-7 cells by estradiol," Molecular Endocrinology, vol. 2, no. 12, pp. 1157-1162, 1988.

[24] C. P. LeBel, H. Ischiropoulos, and S. C. Bondy, "Evaluation of the probe $2^{\prime}, 7^{\prime}$-dichlorofluorescin as an indicator of reactive oxygen species formation and oxidative stress," Chemical Research in Toxicology, vol. 5, no. 2, pp. 227-231, 1992.

[25] X. S. Wan, Z. Zhou, and A. R. Kennedy, "Adaptation of the dichlorofluorescein assay for detection of radiation-induced oxidative stress in cultured cells," Radiation Research, vol. 160, no. 6, pp. 622-630, 2003.

[26] K. Hafer, K. S. Iwamoto, and R. H. Schiestl, "Refinement of the dichlorofluorescein assay for flow cytometric measurement of reactive oxygen species in irradiated and bystander cell populations," Radiation Research, vol. 169, no. 4, pp. 460-468, 2008.

[27] U. Shankarkumar, A. Pawar, P. Gaonkar, D. Parasannavar, V. Salvi, and K. Ghosh, "HLA allele associations in idiopathic recurrent spontaneous abortion patients from India," Journal of Human Reproductive Sciences, vol. 1, no. 1, pp. 19-24, 2008. 
[28] S. F. Martín, H. Sawai, J. M. Villalba, and Y. A. Hannun, "Redox regulation of neutral sphingomyelinase-1 activity in HEK293 cells through a GSH-dependent mechanism," Archives of Biochemistry and Biophysics, vol. 459, no. 2, pp. 295-300, 2007.

[29] F. Tietze, "Enzymic method for quantitative determination of nanogram amounts of total and oxidized glutathione: applications to mammalian blood and other tissues," Analytical Biochemistry, vol. 27, no. 3, pp. 502-522, 1969.

[30] V. C. Abílio, C. C. S. Araujo, M. Bergamo et al., "Vitamin $\mathrm{E}$ attenuates reserpine-induced oral dyskinesia and striatal oxidized glutathione/reduced glutathione ratio (GSSG/GSH) enhancement in rats," Progress in Neuro-Psychopharmacology and Biological Psychiatry, vol. 27, no. 1, pp. 109-114, 2003.

[31] P. Eyer and D. Podhradský, "Evaluation of the micromethod for determination of glutathione using enzymatic cycling and Ellman's reagent," Analytical Biochemistry, vol. 153, no. 1, pp. 5766, 1986.

[32] T. P. M. Akerboom and H. Sies, "Assay of glutathione, glutathione disulfide, and glutathione mixed disulfides in biological samples," Methods in Enzymology, vol. 77, pp. 373-382, 1981.

[33] C. C. Lowry, N. H. Kraeft, and F. A. Hughes Jr., "Blastomycosis of the lung," The American Journal of Surgery, vol. 81, no. 6, pp. 676-679, 1951.

[34] F. R. Bertuchi, R. Papai, M. Ujevic, I. Gaubeur, and G. Cerchiaro, "General chelating action of copper, zinc and iron in mammalian cells," Analytical Methods, vol. 6, no. 21, pp. 84888493, 2014.

[35] J. A. Royall and H. Ischiropoulos, "Evaluation of $2^{\prime}, 7^{\prime}$ dichlorofluorescin and dihydrorhodamine 123 as fluorescent probes for intracellular $\mathrm{H}_{2} \mathrm{O}_{2}$ in cultured endothelial cells," Archives of Biochemistry and Biophysics, vol. 302, no. 2, pp. 348355, 1993.

[36] C. Behl, J. B. Davis, R. Lesley, and D. Schubert, "Hydrogen peroxide mediates amyloid $\beta$ protein toxicity," Cell, vol. 77 , no. 6, pp. 817-827, 1994.

[37] M. Diehn, R. W. Cho, N. A. Lobo et al., "Association of reactive oxygen species levels and radioresistance in cancer stem cells," Nature, vol. 458, no. 7239, pp. 780-783, 2009.

[38] J. M. Estrela, A. Ortega, and E. Obrador, "Glutathione in cancer biology and therapy," Critical Reviews in Clinical Laboratory Sciences, vol. 43, no. 2, pp. 143-181, 2006.

[39] A. Chakraborty, P. Kumar, K. Ghosh, and P. Roy, "Evaluation of a Schiff base copper complex compound as potent anticancer molecule with multiple targets of action," European Journal of Pharmacology, vol. 647, no. 1-3, pp. 1-12, 2010.

[40] M. Arciello, G. Rotilio, and L. Rossi, "Copper-dependent toxicity in SH-SY5Y neuroblastoma cells involves mitochondrial damage," Biochemical and Biophysical Research Communications, vol. 327, no. 2, pp. 454-459, 2005.

[41] J. P. Fruehauf and F. L. Meyskens Jr., "Reactive oxygen species: a breath of life or death?” Clinical Cancer Research, vol. 13, no. 3, pp. 789-794, 2007.

[42] S. Krantic, N. Mechawar, S. Reix, and R. Quirion, "Molecular basis of programmed cell death involved in neurodegeneration," Trends in Neurosciences, vol. 28, no. 12, pp. 670-676, 2005.

[43] O. W. Griffith, "Biologic and pharmacologic regulation of mammalian glutathione synthesis," Free Radical Biology and Medicine, vol. 27, no. 9-10, pp. 922-935, 1999.

[44] T. Okada, K. Murata, R. Hirose et al., "Upregulated expression of FGF13/FHF2 mediates resistance to platinum drugs in cervical cancer cells," Scientific Reports, vol. 3, article 2899, 2013.
[45] A. C. Matias, N. V. dos Santos, R. Chelegão, C. S. Nomura, P. A. Fiorito, and G. Cerchiaro, "Cu(GlyGlyHis) effects on MCF7 cells: copper uptake, reactive oxygen species generation and membrane topography changes," Journal of Inorganic Biochemistry, vol. 116, pp. 172-179, 2012. 


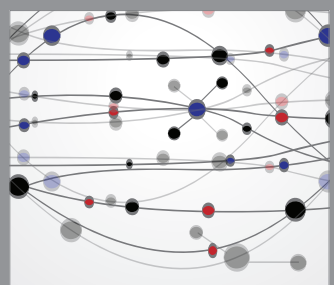

The Scientific World Journal
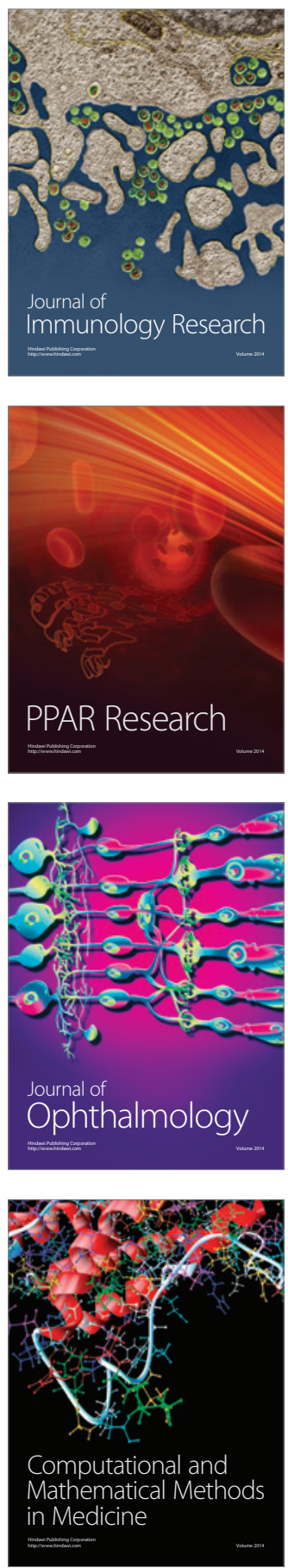

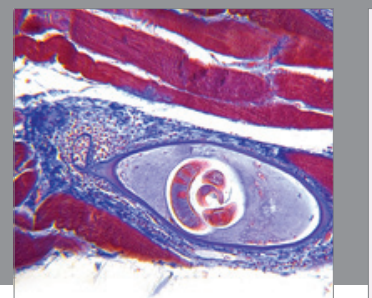

Gastroenterology

Research and Practice
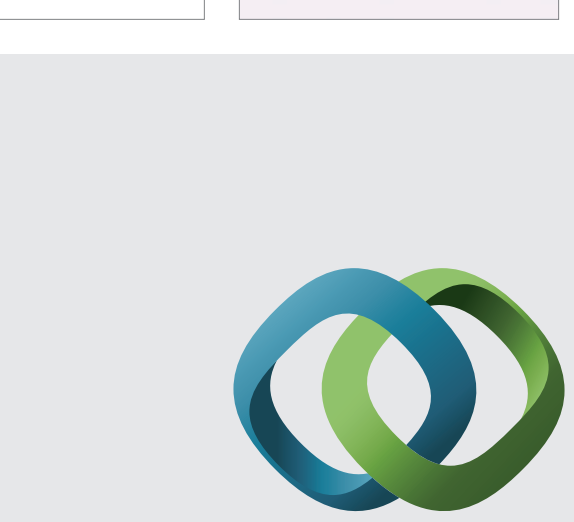

\section{Hindawi}

Submit your manuscripts at

http://www.hindawi.com
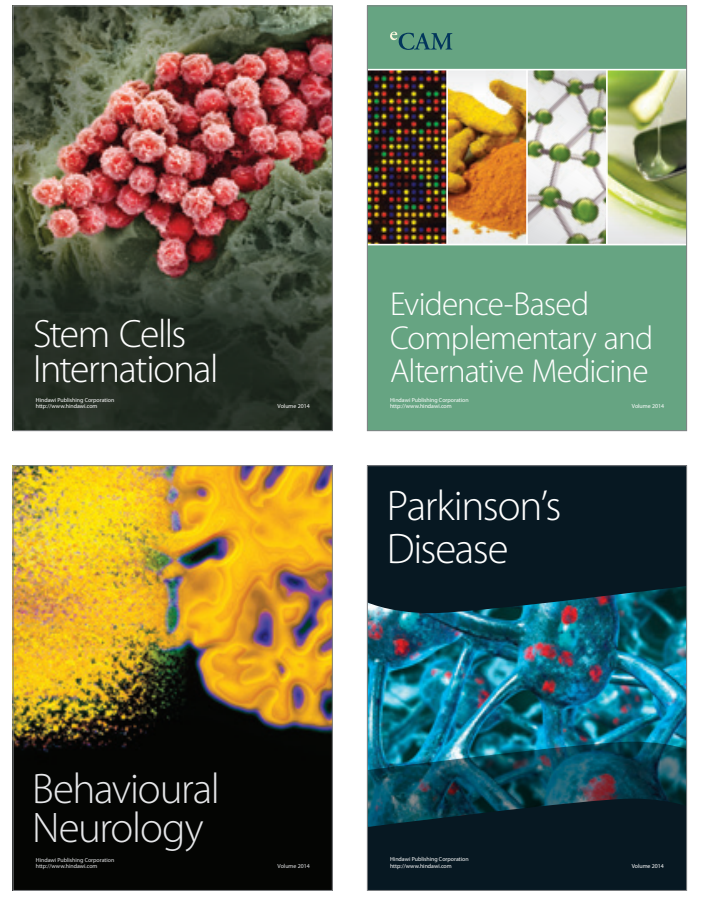
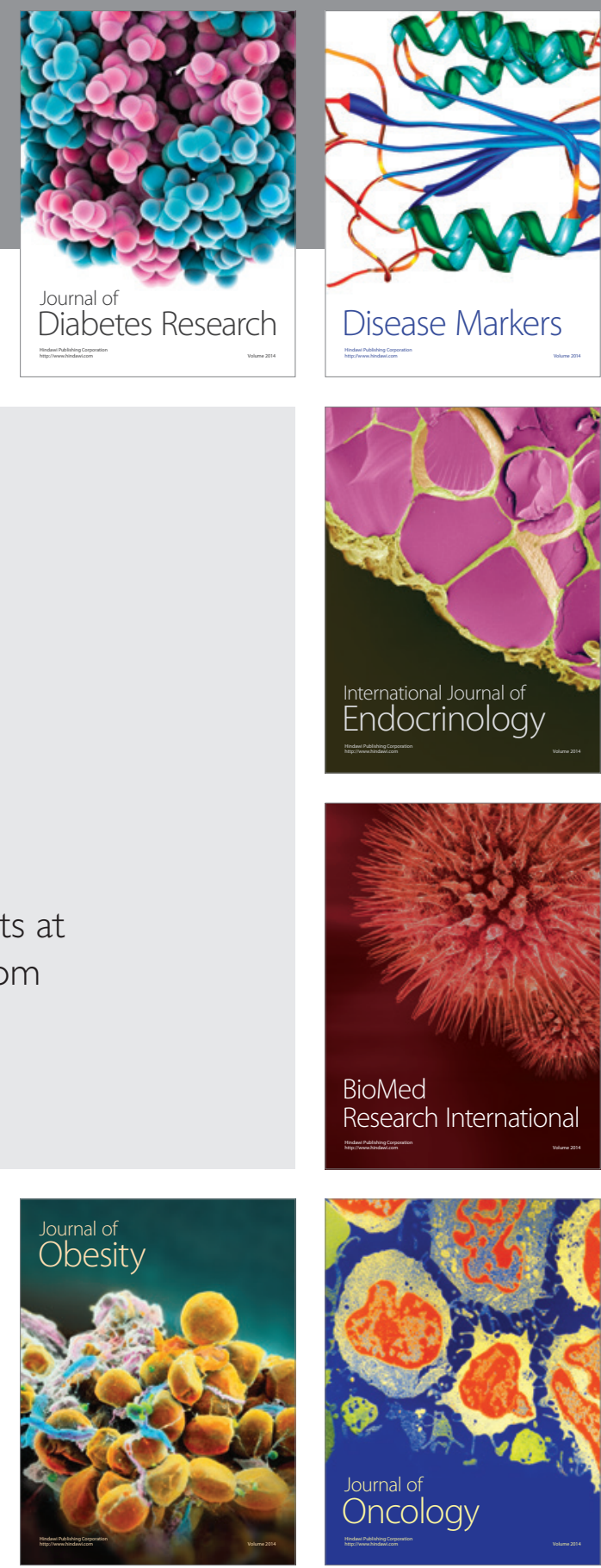

Disease Markers
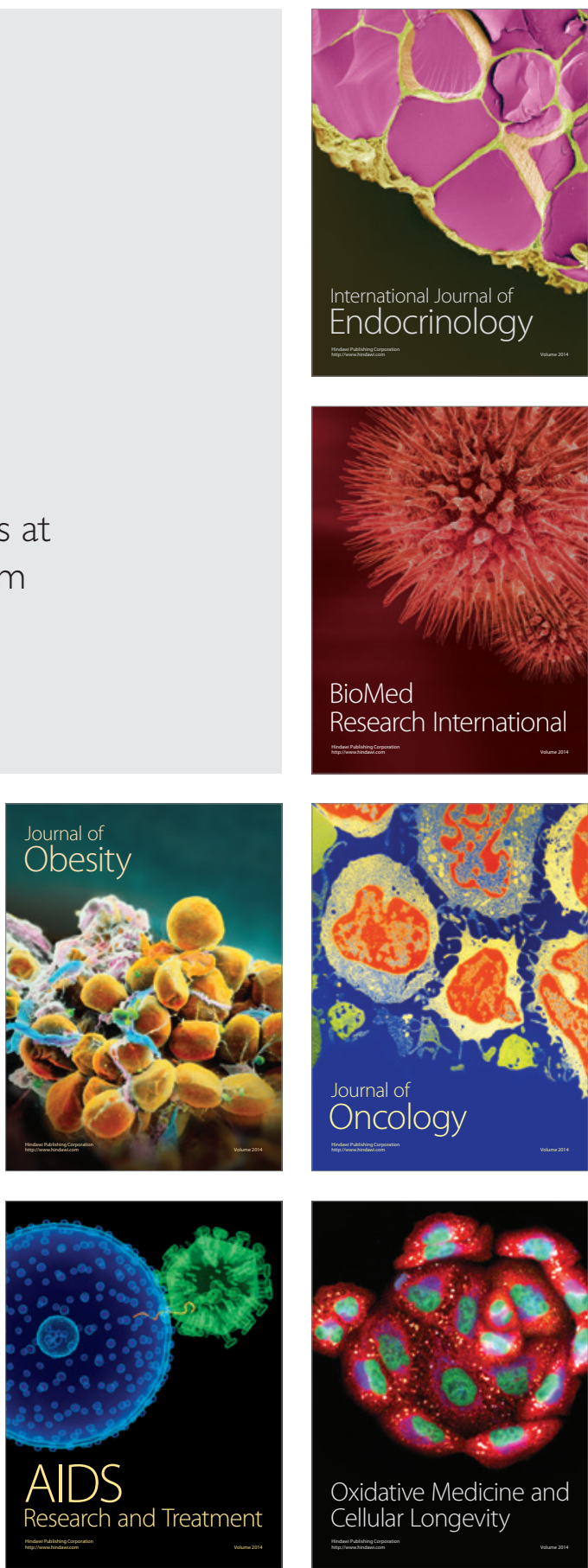